\title{
Molecular Characterization of Swiss Chestnut Cultivars (Castanea Sativa Mill.) Using RAPD, AFLP and ISSR Markers
}

\author{
Abdelhamid, S. ${ }^{{ }^{*}}$, Omri, A. ${ }^{1}$, Araouiki, A. ${ }^{1}$, Sghair A ${ }^{1}$. \\ ${ }^{1}$ Institut de l'Olivier, Laboratoire de Biologie Moléculaire, Cité Taffala, 4000-Sousse, Tunisia
}

\begin{abstract}
Domestic chestnut is one of the most widespread tree species in south Switzerland. It covers more than $26.000 \mathrm{ha}$. In the past, chestnut fruits used to be of vital importance in the diet of people and livestock.

Three different kinds of molecular markers: Random Amplified Polymorphic DNAs (RAPDs), Amplified Fragment Length Polymorphism DNAs (AFLPs) and Inter Simple Sequence Repeats (ISSRs) have been used for studying the genetic variability in 52 Swiss accessions of cultivated and wild Chestnut (Castanea sativa Mill.). Variability within and between cultivars is examined. 98 RAPD, 222 AFLP and 35 ISSR polymorphic markers were amplified using 12, 4 and 5 primers respectively.
\end{abstract}

Clustering analysis performed with the three sets of markers group the 52 studied accessions according to their similarity coefficients separated the genotypes into clear groups with some differences. It is interesting to note that AFLP generated the highest number of polymorphic bands and clustered fairly chestnut cultivars. These results allowed us to resolve problems generated by synonyms and homonyms in different chestnut accessions.

Molecular markers results are comparable. The similarity matrices based on the three sets of data give a high significant correlation between RAPD and AFLP, RAPD and ISSR data ( $r=0.78$ and $r=0.75$ respectively).

Keywords: Castanea sativa, molecular markers, genetic diversity, RAPD, AFLP, ISSR.

\section{INTRODUCTION}

Chestnut was cultivated since the Roman Empire. Cultivated chestnut has colonized many European environments. It is a typical nut crop in many mountainous regions of the European area and one of the most common forest trees in the southern alps of Switzerland since nearly 2000 years (Conedera et al., 1997). Swiss Alps accounts approximately 26000 ha of chestnut forests which was wide spread into 250 town ships. A total of 94 names of chestnut varieties are known. In Southern Alps, chestnut was considered as an important source of food. Moreover, chestnut is widely known for its double usefulness. Its fruit was used for nutrition (man and animal) and its wood is a means for providing either fire or stokes. Numerous cases of homonymy and synonymy could occur in different traditional chestnut areas in Switzerland (Gobbin et al., 2007). Despite the great number of existing varieties, the need for a powerful identification and characterization method in wild and cultivated varieties is crucial.

Typically, the characterisation of Swiss chestnut cultivars was based on morphological traits such as fruit and leaves has been used to verify the identity of uncertain cultivars. Moreover, this approach yielded considerable redundant number of different chestnut cultivars. However, because of most discriminating characters is related to fruit and flower, morphological identification has to be completed by a molecular approach.

Some authors applied isozymes techniques to identify and to study the genetic variability of European chestnut (Pereira et al., 1999). The use of isozyme markers to characterize and to study the genetic variation between and within cultivars, depend on several factors (environmental, limited in number) that limit the wider adoption of this technique (Pereira-Lorenzo et al., 1996).

Recently, molecular markers were used to identify chestnut clones and cultivars (Angela Martin et al., 2010). DNA molecular markers techniques based on in-vitro enzymatic amplification of specific fragments of DNA via PCR (polymerase chain reaction) are of greater suitability in genetic diversity estimations and identification of chestnut genotypes (Casasoli et al., 2006; Mellano et al., 2012; 
Abdelhamid, S et al.

McCleary et al., 2013). Previous studies have assessed the genetic variability of chestnut using Random Amplified Polymorphic DNA (RAPDs) (Oraguzie et al., 1999), Amplified Fragment Length Polymorphism (AFLPs) (Yamamoto et al., 1998), Inter Simple Sequence Repeats (ISSRs) (Goulăo et al., 2001; Casasoli et al., 2001) and Simple Sequence Repeats (SSRs or Microsatellites) (PereiraLorenzo et al., 2011).

The objective of this study were (i) to assess the relative efficiencies of different molecular markers and (ii) to compare different molecular marker systems for genetic diversity analysis and to assess the extent of genetic variability available within and among cultivated cultivars and natural chestnut of coppice shoots.

\section{Material AND MeThodS}

\subsection{Plant Material and DNA Extraction}

In the present study, 52 accessions were collected from morphologically different varieties of different areas in southern Switzerland. The origin of studied accessions of Swiss varieties and coppice shoots are listed in Tab. 1.

Table1. Studied accessions of Swiss chestnut genotypes and their origin

\begin{tabular}{|l|l|l|}
\hline Accession order & Genotype & Origin/Locality \\
\hline 1 & Verdanesa & Calonico 01. Switzerland \\
\hline 2 & Verdanesa & Calonico 04. Switzerland \\
\hline 3 & Verdanesa & Giornico 03. Switzerland \\
\hline 4 & Verdanesa & Giornico 06. Switzerland \\
\hline 5 & Verdanesa & Giornico 04. Switzerland \\
\hline 6 & Verdanesa & Chironico 02. Switzerland \\
\hline 7 & Verdanesa & Chironico 06. Switzerland \\
\hline 8 & Verdanesa & Chironico 10. Switzerland \\
\hline 9 & Verdanesa & Chironico 12. Switzerland \\
\hline 10 & Verdanesa & Chironico 13. Switzerland \\
\hline 11 & Verdanesa & Lodrino 04. Switzerland \\
\hline 12 & Verdanesa & Torricella 10. Switzerland \\
\hline 13 & Verdanesa & Torricella 13. Switzerland \\
\hline 14 & Lüina & Calonico 02. Switzerland \\
\hline 15 & Lüina & Calonico 07. Switzerland \\
\hline 16 & Lüina & Giornico 01. Switzerland \\
\hline 17 & Lüina & Giornico 02. Switzerland \\
\hline 18 & Lüina & Chironico 01. Switzerland \\
\hline 19 & Lüina & Chironico 05. Switzerland \\
\hline 20 & Lüina & Chironico 08. Switzerland \\
\hline 21 & Lüina & Chironico 14. Switzerland \\
\hline 22 & Lüina & Lodrino 03. Switzerland \\
\hline 23 & Lüina & Lodrino 05. Switzerland \\
\hline 24 & Lüina & Lodrino 14. Switzerland \\
\hline 25 & Lüina & Torricella 08. Switzerland \\
\hline 26 & Lüina & Torricella 09. Switzerland \\
\hline 27 & Lüina & Torricella 17. Switzerland \\
\hline 28 & Bonè negro & Calonico 03. Switzerland \\
\hline 29 & Bonè negro & Calonico 05. Switzerland \\
\hline 30 & Bonè negro & Calonico 06. Switzerland \\
\hline 31 & Bonè negro & Calonico 08. Switzerland \\
\hline 32 & Bonè negro & Chironico 03. Switzerland \\
\hline 33 & Bonè negro & Chironico 04. Switzerland \\
\hline 34 & Bonè negro & Lodrino 02. Switzerland \\
\hline 35 & Bonè negro & Lodrino 11. Switzerland \\
\hline 36 & Bonè negro & Lodrino 12. Switzerland \\
\hline & & \\
\hline & & \\
\hline 12 & & \\
\hline & &
\end{tabular}


Molecular Characterization of Swiss Chestnut Cultivars (Castanea Sativa Mill.) Using RAPD, AFLP and ISSR Markers.

\begin{tabular}{|l|l|l|}
\hline 37 & Bonè negro & Lodrino 13. Switzerland \\
\hline 38 & Berögna & Lodrino 07. Switzerland \\
\hline 39 & Berögna & Lodrino 08. Switzerland \\
\hline 40 & Berögna & Prosita 07. Switzerland \\
\hline 41 & Pinca & Vezio 21. Switzerland \\
\hline 42 & Pinca & Vezio 22. Switzerland \\
\hline 43 & Pinca & Vezio 31. Switzerland \\
\hline 44 & C. sativa: Coppice & East Switzerland \\
\hline 45 & C. sativa: Coppice & East Switzerland \\
\hline 46 & C. sativa: Coppice & East Switzerland \\
\hline 47 & C. sativa: Coppice & East Switzerland \\
\hline 48 & C. sativa: Coppice & East Switzerland \\
\hline 49 & C. sativa: Coppice & East Switzerland \\
\hline 50 & C. sativa: Coppice & East Switzerland \\
\hline 51 & C. sativa: Coppice & East Switzerland \\
\hline 52 & C. sativa: Coppice & East Switzerland \\
\hline
\end{tabular}

Total DNA was extracted from small leaves using hexadecyltrimethyl ammonium bromide (CTAB) according to the method described by Porebski et al. (1997). DNA was resuspended in TE (pH 8) solution and stored at $-20{ }^{\circ} \mathrm{C}$.

\subsection{DNA Amplification}

\section{RAPD}

Using RAPD method, 12 primers from set OPA 02, 04, 07,10 and 15, OPB 08, OPD 20, OPE 01, 04, 16 and 19 and OPX 17 (Operon Technologies, Alameda, Calif.), were able to amplify specific markers.

PCR were performed in a total volume of $25-\mu$. The amplification reaction contained $1 \times$ PCR buffer, $1.4 \mathrm{mM} \mathrm{MgCl} 2,0.2 \mathrm{mM}$ dNTP, $0.4 \mu \mathrm{M}$ primer, $1 \mathrm{U} / \mu \mathrm{l}$ Taq polymerase (Eurobiotaq) and $20 \mathrm{ng} / \mu \mathrm{l}$ template DNA. PCR was performed in a Hybaid PCR express thermal cycler (HBP x 220) with following cycling profile: an initial denaturation at $94{ }^{\circ} \mathrm{C}$ for $4 \mathrm{~min}$, followed by 38 cycles of $1 \mathrm{~min}$ at $93{ }^{\circ} \mathrm{C}, 1 \mathrm{~min}$ at $45^{\circ} \mathrm{C}$ and $1 \mathrm{~min}$ at $72^{\circ} \mathrm{C}$ with a final extension at $72{ }^{\circ} \mathrm{C}$ for $5 \mathrm{mn}$. The DNA fragments were then visualized under UV light.

\section{AFLP}

For AFLP, 4 sets of selective primer combinations were used (E-AGG/M-CTT, E-AAC/M-CTT, EAGT/M-CAT and E-AAC/M-CAT) from the GIBCO BRL AFLP ${ }^{\mathrm{TM}}$ Core Reagent Kit to generate AFLP fragments.

Digestion was done with $5 \mathrm{U}$ of EcoRI and $5 \mathrm{U}$ of $M s e \mathrm{I}$ (Biolabs) in T4-buffer. For the ligation reaction, the following mixture was added to the restriction-reaction mixture; EcoRI adapter ( $40 \mathrm{p}$ $\mathrm{mol} / \mu \mathrm{l}), M s e \mathrm{I}$ adapter (40 p mol/ $\mu \mathrm{l}), 1 \mathrm{U}$ T4 DNA ligase, 1 x T4 DNA ligase buffer and incubated for $3 \mathrm{~h}$ at $37^{\circ} \mathrm{C}$.

Preamplification was carried out in volumes of $20-\mu$. Reactions contained 1 x PCR buffer, $1.5 \mathrm{mM}$ $\mathrm{MgCl}_{2}, 1 \mathrm{mM} \mathrm{dNTP}, 10 \mathrm{pmol} / \mu \mathrm{l}$ for each preselective primer EcoRI-A and MseI-C, $1 \mathrm{U}$ Taq polymerase (Qiagen AG, Basel) and $100 \mathrm{ng} / \mu$ l template DNA. Preamplification was performed with the cycling following profile: $2 \mathrm{~min}$ DNA denaturation step at $94{ }^{\circ} \mathrm{C}$, followed by 28 cycles of $45 \mathrm{sec}$ at $94{ }^{\circ} \mathrm{C}, 45 \mathrm{sec}$ at $56{ }^{\circ} \mathrm{C}$ and $1 \mathrm{~min}$ at $72{ }^{\circ} \mathrm{C}$. A final elongation step was done at $72{ }^{\circ} \mathrm{C}$ for $10 \mathrm{~min}$.

Selective Amplification reactions were performed in $20-\mu 1$ volume contained 1 x PCR buffer,

$0.75 \mathrm{mM} \mathrm{MgCl} 2,1 \mathrm{mM}$ dNTP, $0.25 \mu \mathrm{M}$ of each selective primers EcoRI-ANN and MseI-CNN, $1 \mathrm{U}$ Taq polymerase (Qiagen AG, Basel). PCR was performed for 36 cycles with the following cycle profile: a $30 \mathrm{~s}$ DNA denaturation step at $94{ }^{\circ} \mathrm{C}$, a $30 \mathrm{~s}$ annealing step and a 1 min extension step at 72 
Abdelhamid, $\mathbf{S}$ et al.

${ }^{\circ} \mathrm{C}$. Samples were loaded and run on the ABI-310 automated DNA sequencer (capillary electrophoresis).

\section{ISSR}

According to ISSRs method, 5 primers were selected UBC 810, UBC 834, UBC 836, UBC 841 and UBC 890 (obtained from UBC primer set 100/9, University of British Columbia, Canada) based on their capacity to amplify polymorphic fragments.

Amplification reactions were carried out in volumes of $25-\mu$. Reaction contained $1 \mathrm{x}$ PCR buffer, 1.4 $\mathrm{mM} \mathrm{MgCl} 2,0.2 \mathrm{mM} \mathrm{dNTP}, 0.4 \mu \mathrm{M}$ of primer, $1 \mathrm{U} / \mu \mathrm{l} \mathrm{Taq}$ polymerase (Eurobiotaq) and $30 \mathrm{ng} / \mu \mathrm{l}$ template DNA. PCR reactions were performed with the following conditions: $4 \mathrm{~min}$ at $94^{\circ} \mathrm{C}$ for initial denaturation, 35 cycles of $35 \mathrm{~s}$ at $93{ }^{\circ} \mathrm{C}$ (denaturation), $45 \mathrm{~s}$ at optimal temperature ranging from 52 ${ }^{\circ} \mathrm{C}$ to $55{ }^{\circ} \mathrm{C}$ (annealing) and $90 \mathrm{sec}$ at $72{ }^{\circ} \mathrm{C}$ (extension). A final extension step at $72{ }^{\circ} \mathrm{C}$ for $5 \mathrm{~min}$ followed. PCR products were separated on denaturing polyacrylamide gels multiphor II (Pharmacia Biotech) DNA silver staining kit (Pharmacia Biotech).

\subsection{Data Scoring and Analysis}

Polymorphic DNA fragments for the three types of markers were scored as present (1) or absent (0). Dendrograms were constructed by UPGMA (Unweighted Pair-Group Method with Arithmetic Averages) cluster analysis according to Jaccard's coefficient (Sneath and Sokal 1973) using the cluster (http:www.biology.ualberta.ca/jbrzusto) analysis software, and then visualized with TREEVIEW program (Page 1998). The coefficient of similarity was calculated (Sneath and Sokal 1973) and then similarity matrices were calculated to perform Principal Coordinates Analysis (PCoA).

The correlation between RAPD, AFLP and ISSR methods was investigated by the Mantel test of matrix correspondence (Mantel 1967). Mantel's tests were performed with the R4 (Beta version) package (Philippe Casgrain \& Pierre Legendre, Dép. Des sciences biologiques, Université de Montréal) and statistical significance was determined by random permutation (999 permutations).

\section{ReSUlts AND DiscuSSION}

The three methods used in this study were able to uniquely fingerprint each of the 52 cultivated chestnut accessions and were efficient in the characterization of chestnut cultivars. The 12 RAPD primers used on the whole set of plants produced a total of 98 polymorphic bands. For all the genotypes, the highest number of polymorphic and scorable bands was obtained by primer OPE-01 (10 fragments). For AFLP, the four primer combinations (E-AGG/M-CTT, E-AAC/M-CTT, EAGT/M-CAT and E-AAC/M-CAT) yielded 222 polymorphic fragments with an average of 55 polymorphic bands per reaction, which ranged from 50 to $350 \mathrm{bp}$. For ISSR, five primers amplified bands, which are visible in polyacrylamide gels. The 5 ISSR primers detected a total of 35 polymorphic fragments with an average of 7 polymorphic bands per reaction. The highest number of polymorphic bands was obtained by primer UBC-841. Our present study is largely in accordance and comparable with previous work (Abdelhamid et al., 2014) using molecular markers genetic analysis method to assess the genetic variability of Castanea species.

In all dendrograms generated by the three methods, the species of $C$. sativa was clustered into two groups: the first cluster is composed of Swiss cultivars and the second is composed of coppice shoots Fig. (1-4). Swiss cultivars are used for nut production, whereas coppice shoots are basically used for wood production. The different uses for special ends relating to such group explain in a way the division formerly showed by dendrograms. The grouping of Swiss cultivars and coppice shoots into two different clusters by all the dendrograms may suggest that grafting methods, generally practised by farmers, for chestnut propagation, could have transformed natural forests into clonal or polyclonal fruit orchard. 
Molecular Characterization of Swiss Chestnut Cultivars (Castanea Sativa Mill.) Using RAPD, AFLP and ISSR Markers.

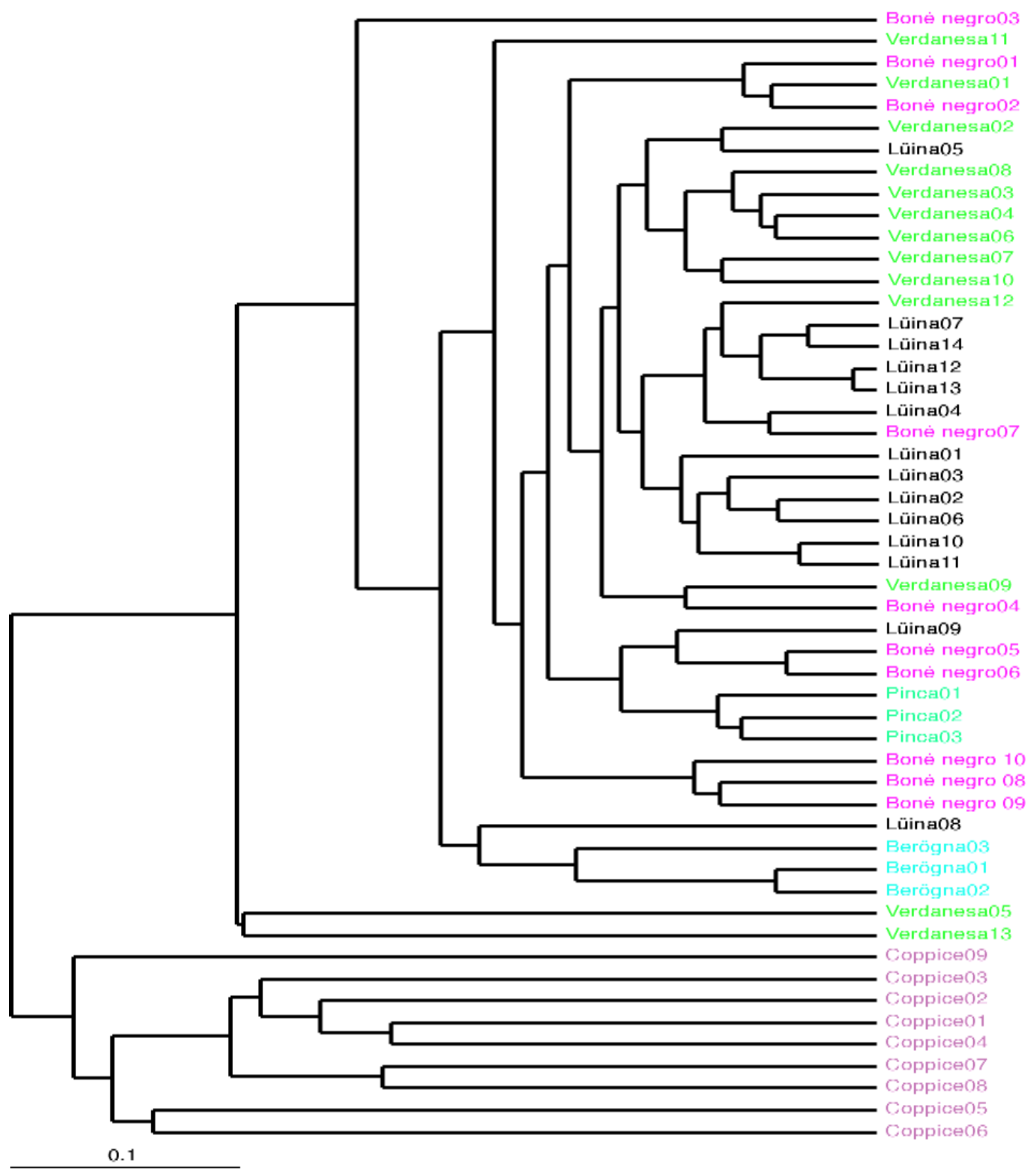

Fig1. UPGMA dendrogram obtained using RAPD analysis. 


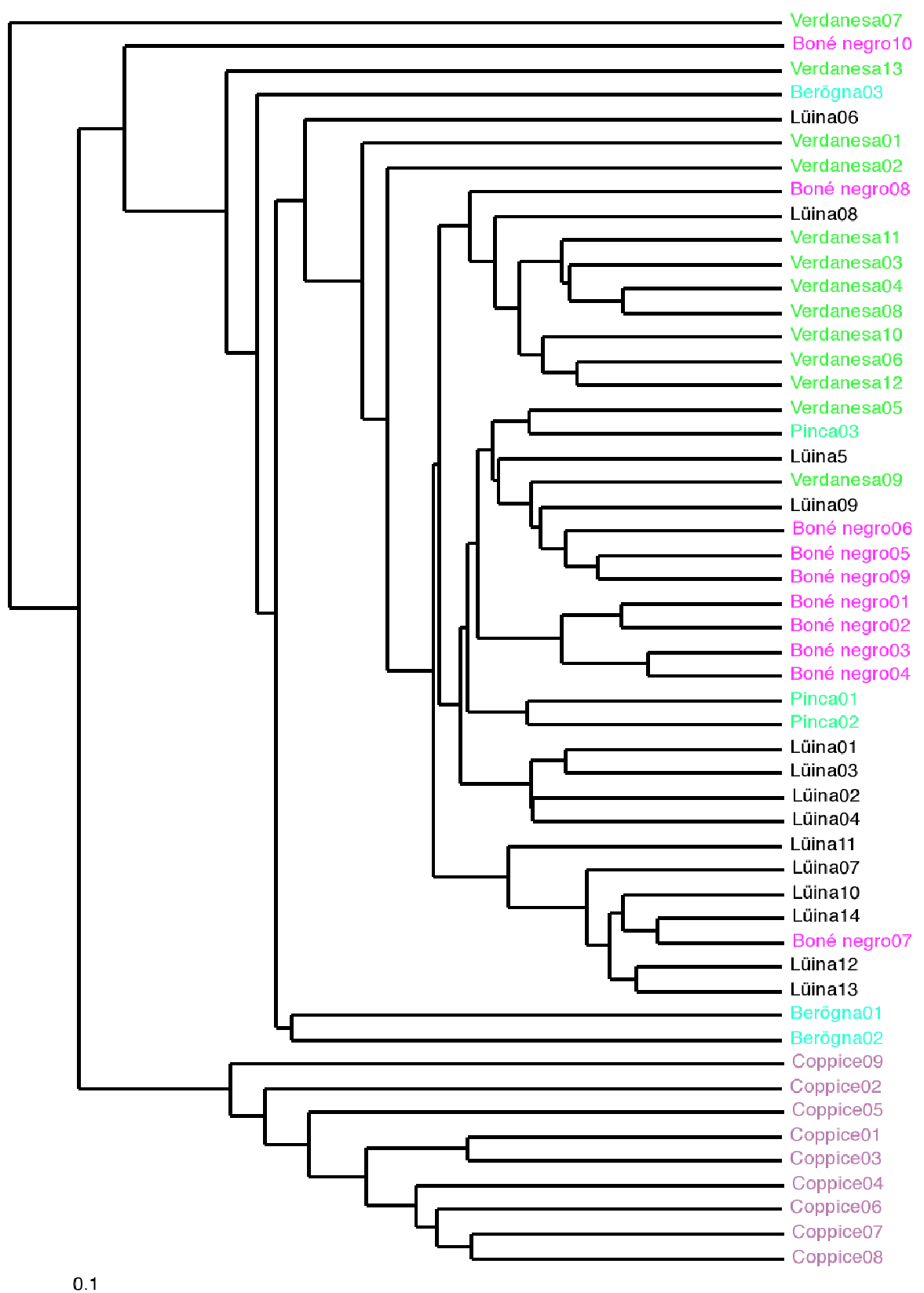

Fig2. UPGMA dendrogram obtained using AFLP analysis. 


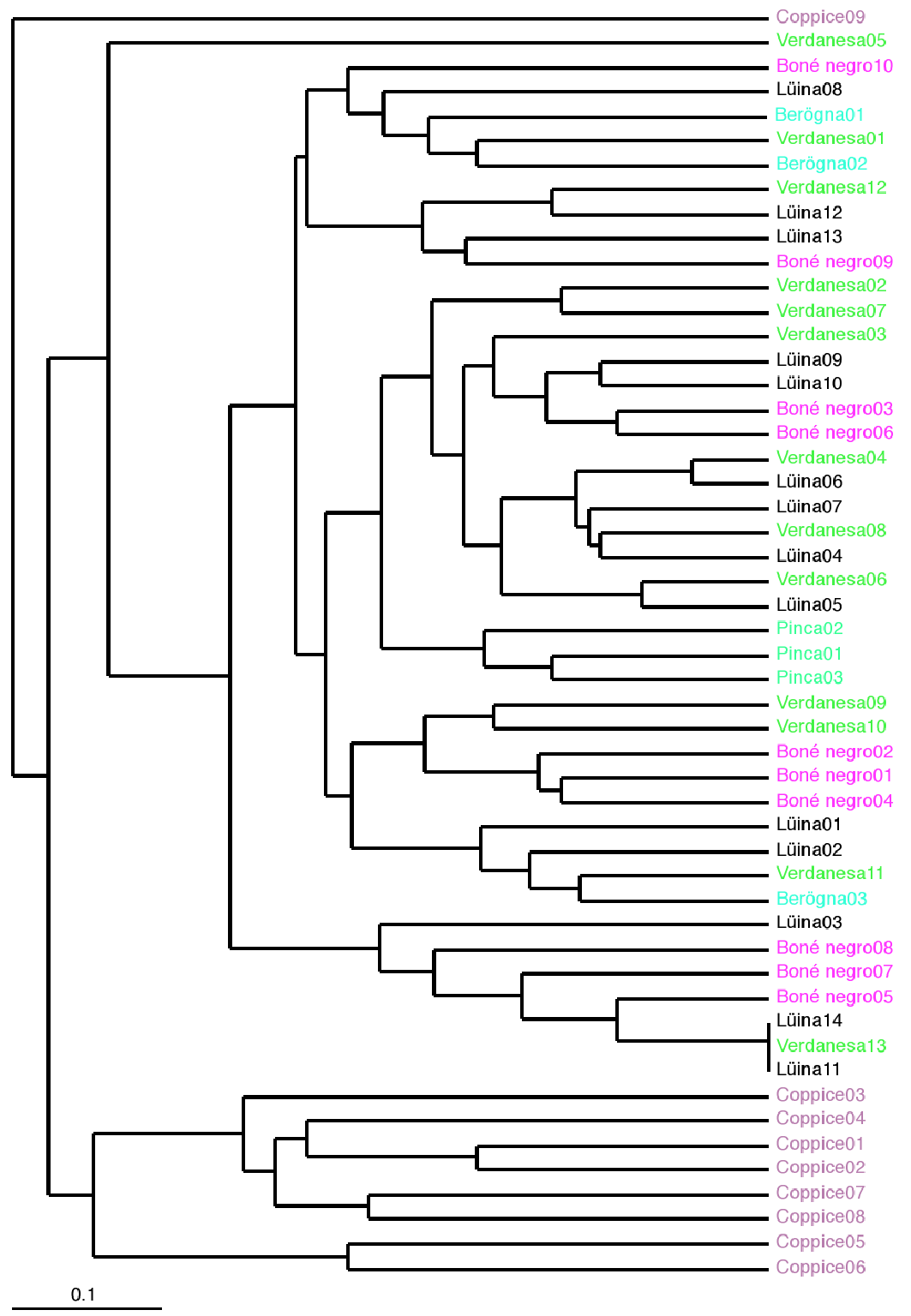

Fig3. UPGMA dendrogram obtained using ISSR analysis. 


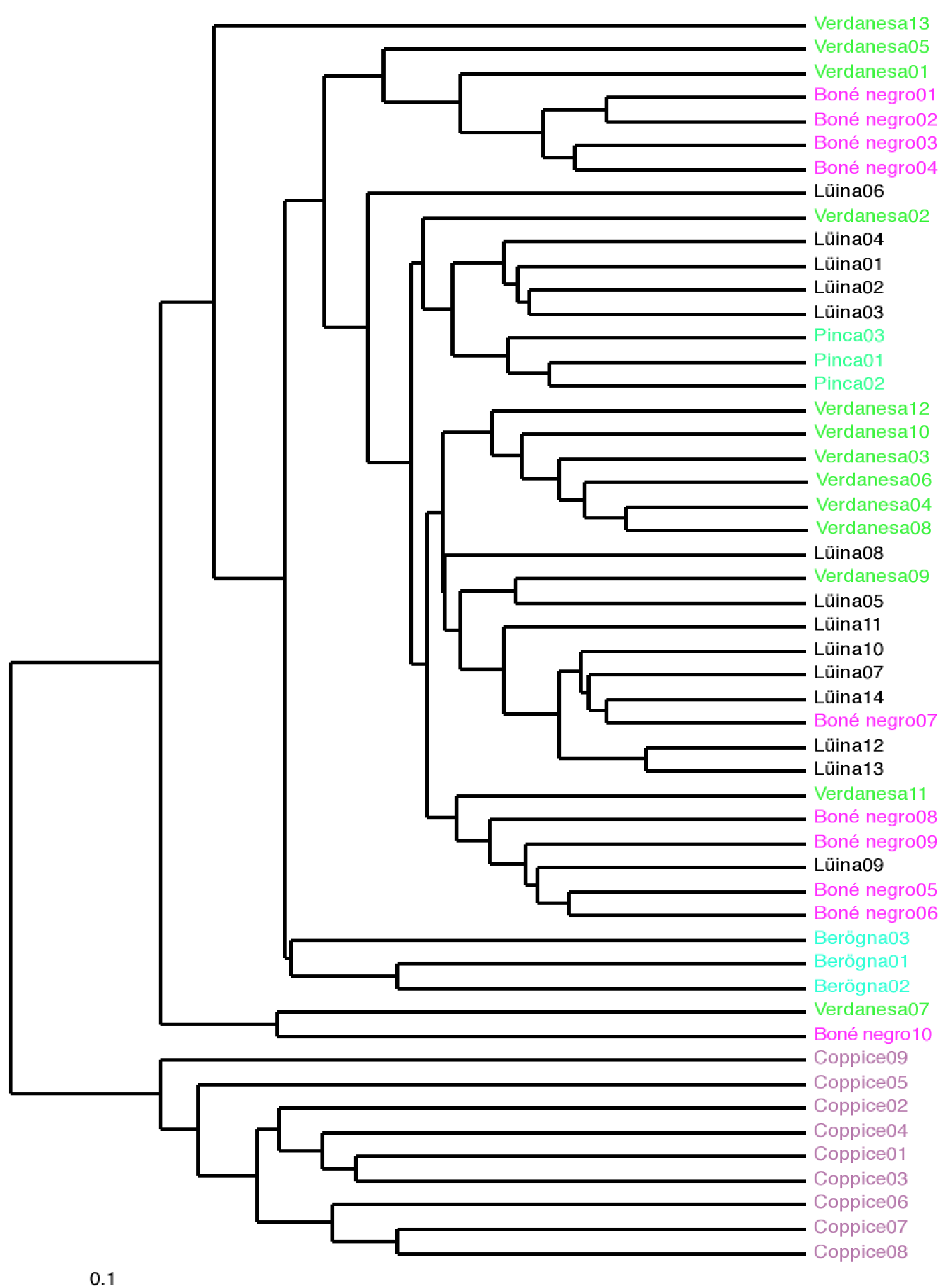

Fig.4. UPGMA dendrogram obtained using combined data analysis.

The three methods mentioned above show that Swiss cultivars are genetically closely related, our results agreed with the results based on morphological traits (Martín et al., 2007), this may be explained by the fact that southern Switzerland is a rich assortment of polyclonal varieties, which are the results of a clonal selection process, generally done by farmers in terms of their needs or in terms 
of their aspiration to superior quality of chestnut fruit. The agro-ecological adaptation area of cultivars (not wide geographical distribution), a possible exchange of plant material and seed among the different regions of southern Switzerland and the old cultural traditions may explain the homogeneity among cultivars.

RAPDs and combined data ordered Pinca and Berögna, as expected, according to the supposed affiliation to a variety. Also, ISSRs cluster Pinca in a clear distinct group.

Discrepancies in forming clear groups within Lüina, Verdanesa and Boné negro varieties were observed in dendrograms produced by all the kind of markers.

Furthermore, RAPD, AFLP and combined data clustered clearly Lüina, Verdanesa and Boné negro, though with exceptions, into separate groups. ISSR did not separate accessions of cultivars clearly. It seems interesting to mention that several small groups of accessions have been formed that made identification very difficult. This was the case for the three cultivars: Verdanesa, Lüina and Boné negro.

The molecular markers data did not discriminate clearly Swiss cultivars, while combined data show a clear discrimination of cultivars that appear to be more clearly clustered in separated groups in the plot.

RAPDs, AFLPs and combined data provided fairly a clear separation of cultivars which were positioned within varieties. Boné negro 07 and Verdanesa 12 were closely related to Lüina, Lüina 05 was closely related to Verdanesa and Lüina 09 was related to Boné negro as shown by RAPD. For AFLP, Lüina 08, Boné negro 08 were clustered with Verdanesa and Boné negro 07 was related to Lüina cultivars.

RAPD and combined data methods could separate two cultivars (Pinca and Berögna) in a clear distinct group showing some similarity in clustering cultivars. Also, ISSR cluster accessions of Pinca in one distinct group.

Considering the Verdanesa related accessions, the topology of each tree revealed with RAPD, AFLP and combined data sets is unique with some similarity. There was not very good discrimination of Verdanesa cultivars by ISSR.

Lüina variety was mainly constituted by Lüina 01, 02, 03, 04, 07, 10, 11, 12, 13, 14 accessions and was consistently reported by RAPD, AFLP and combined data, with some exceptions. A not clear discrimination among accessions showed by ISSR dendrogram.

Four accessions of Boné negro cultivars (Boné negro 01, 02, 05 and 06) were clustered together by RAPD, AFLP and combined data and formed a clear group. Dendrogram generated by ISSR could not clearly distinguish accessions of Boné negro.

The results obtained with the three methods indicate that Verdanesa, Lüina, pinca, Berögna and verdanesa are genetically related. This result could be explained by the common origin of European chestnut trees. As reported by some previous studies (Fineshi et al., 2000), shown that European chestnuts were coming from the east and were widely diffused in Europe by human activities. Other data related to Italian (Pigliucci et al., 1990; Villani et al.,1991; Mancuso et al., 1999), Portuguese (Seabra et al., 2001) and on Spanish chestnut (Pereira-Lorenzo et al., 1996) (studies based on isozyme traits) showed a close relationship among varieties as well.

High genetic similarities between and within Swiss cultivars were shown by the three used markers analysis. Similar results are found by (Gobbin et al., 2007) and show that Swiss varieties appear morphologically more uniform. The same authors confirm this genetic uniformity among cultivars by isozymes traits. The same findings were confirmed by Conedera et al. (1993), who showed that those varieties are morphologically homogenous and have a similar architecture of the crown. Also, the asexual propagation through grafting and crossing between trees affects the closeness of the genetic relationships among cultivars.

As for the intracultivar polymorphism, dendrograms obtained from RAPD and combined data separated Pinca and Berögna into distinct groups. This clustering may be explained by the low number of accessions per variety (3 individuals); moreover, those varieties are regionally distributed: 
individuals from the former have the same centre of origin (Lodrino), so as individuals from the later have been sampled from the same area of origin (Vezio).

Mantel test indicated a high correlation between matrices based on AFLPs and RAPDs ( $r=0.78)$. The high correlation confirmed the similarity of clustering cultivars by these types of markers. Also, a high Mantel's test correlation was found between RAPDs and ISSRs data $(r=0.75)(T a b .2)$.

Table2. (Mantel's $r$ ) Correlation coefficients of a distance matrix created by RAPDs, AFLPS and ISSRs markers. Correlations were highly significant (**: $P<0.01)$.

\begin{tabular}{|l|l|l|l|}
\hline AFLP & & & \\
\hline ISSR & $0.50^{* *}$ & & \\
\hline RAPD & $0.78^{* *}$ & $0.75^{* *}$ & \\
\hline Combined data & $0.48^{*}$ & 0.26 & 0.36 \\
\hline & AFLP & ISSR & RAPD \\
\hline
\end{tabular}

The complementarity between the two methods in the identification of cultivars was confirmed by a high correlation between the two types of markers $(r=0.78)$. RAPD and AFLP markers also allowed us to solve problems generated by synonyms and homonyms in different accessions. Those methods allowed us to prove that some accessions with different names, which could have been considered as different cultivars, were actually closely related, showing a very similar or identical genotype, such as for example, in the case of Boné négro 07 that was suspected to be similar to Lüina cultivars. This result was confirmed by the dendrogram revealed by combined data. Method based on ISSR's discriminate not clearly accessions of cultivated Swiss cultivars. These results may be explained by the fact that AFLP and RAPD yielded a large number of polymorphic bands (222 and 98 respectively); while a low number of markers was produced by ISSR (35). This result was confirmed by the high correlation between combined data and AFLP (0.48) and between RAPD and AFLP data (0.78). Both are dominant markers but AFLP can generate a larger number of polymorphic bands per primer combination (222 vs. 98 ) in our study.

Moreover, the use of additional primers may contribute to better distinction among accessions (Cervera et al., 1996).

\section{REFERENCES}

[1] Abdelhamid, S., Công-Linh, L., Conedera, M., Kûpfer, Ph. (2014). The assessment of genetic diversity of Castanea species by RAPD, AFLP, ISSR and SSR markers. Turk J Bot, 38, 835850 .

[2] Angela Martin, M., Mattioni, C., Cherubini, M., Taurchini, D., Villani, F. (2010). Genetic diversity in European chestnut populations by means of genomic and genic microsatellite markers. Tree Genet Genom, 6, 735-744.DOI 10.1007/s11295-010-0287-9.

[3] Casasoli, M., Mattioni, C., Cherubini, M., Villani, F. (2001). A genetic linkage map of European chestnut (Castanea sativa Mill.) based on RAPD, ISSR and isozyme markers. Theor Appl Genet, 102, 1190-1199.

[4] Casasoli, M., Derory, J., Morera-Dutrey, C., Brendel, O., Porth, I., Guehl, J.M., Villani, F., Kremer, A. (2006). Comparison of Quantitative Trait Loci for Adaptive Traits Between Oak and Chestnut Based on an Expressed Sequence Tag Consensus Map. Genetics, 172, 533-546.

[5] Cervera, M.T., Gusmao, J., Steenackers, M., Van Gysel, A. (1996). Application of AFLP ${ }^{\mathrm{TM}}$ based molecular markers to breeding of Populus spp. Plant growth Regulation, 20, 47-52.

[6] Martín, M.A., Moral, A., Martín, L.M., Alvarez, J.B. (2007). The genetic resources of European sweet chestnut (Castanea sativa Miller) in Andalusia, Spain. Genet Resour Crop Evol, 54, 379387.

[7] Conedera, M., Jermini, M., Sassella, A. (1997). Nouvelles perspectives pour la culture du châtaignier au sud des Alpes. Revue Suisse Vitic Arboric Hortic. 29, 01-07.

[8] Fineschi, S., Taurchini, D., Villani, F., Vendramin, G.G. (2000). Choroplast DNA polymorphism reveals little geographical structure in Castanea sativa Mill. (Fagaceae) throughout southern European countries. Mol Ecol, 10, 1495-1504.

[9] Gobbin, D., Hohl, L., Conza, L., Jermini, M., Gessler, C., Conedera, M. (2007). Microsatellitebased characterization of the Castanea sativa cultivar heritage of southern Switzerland. Genome, 50, 1089-1103. 
[10] Goulão, L., Valdiviesso, T., Santana, C., Moniz Oliveira, C. (2001). Comparison between phenetic characterisation using RAPD and ISSR markers and phenotypic data of cultivated chestnut (Castanea sativa Mill.). Genet Resour Crop Evol, 48, 329-338.

[11] Mancuso, S., Ferrini, F., Nicese, F.P. (1999). Chestnut (Castanea sativa Mill.) genotype identification: An artificial neural network approach. J Hortic Sci Biotech, 74, 777-784.

[12] Mantel, N. (1967). The detection of disease clustering and a generalized regression approach. Cancer Res, 27, 209-220.

[13] Mellano, M.G., Beccaro, G.L., Donno, D., Torello Marinoni, D., Boccacci, P., Canterino, S., Cerutti, A.K., Bounous, G. (2012). Castanea spp. biodiversity conservation: collection and characterization of the genetic diversity of an endangered species. Genet Resour Crop Evol, 59, 1727-1741. DOI 10.1007/s10722-012-9794-x.

[14] McCleary, T., McAllister, M., Coggeshall, M., Romero-Severson, J. (2013). EST-SSR markers reveal synonymies, homonymies and relationships inconsistent with putative pedigrees in chestnut cultivars. Genet Resour Crop Evol, 60, 1209-1222. DOI 0.1007/s10722-012-9912-9.

[15] Oraguzie, N.C., Paterson, A.M., McNeil, D.L. (1999). Origin and relationships of New Zealand chestnut (Castanea sp. Fagaceae) selections reflect patterns of graft failure. Plant Syst Evol, 218, 193-204.

[16] Page, R.D.M. (1998). Tree drawing software for Apple Macintosh and Microsoft Windows, Division of Environmental and Evolutionary Biology, Institute of Biomedical and Life Science, University of Glasgow.

[17] Pereira-Lorenzo, S., Fernandez-Lopez, J., Moreno-Gonzalez, j. (1996). Variability and grouping of Northwestern Spanish Chestnut cultivars.II. Isoenzyme traits. J Am Soc Hortic Sci, 121, 190197.

[18] Pereira-Lorenzo, S., Costa, R.M.L., Ramos-Cabrer, A.M., Ciordia-Ara, M., Ribeiro C.A.M., Borges, O., Barreneche, T. (2011). Chestnut cultivar diversification process in the Iberian Peninsula, Canary Islands, and Azores. Genome, 54, 301-315. doi:10.1139/G10-122.

[19] Pereira, M.J., Castro, L.F., Torrea-Pereira, J.M., Lorenzo, S.P. (1999). Isozyme polymorphisms in Portuguese chestnut cultivars. Acta Hortic, 494, 283-286.

[20] Pigliucci, M., Benedetelli, S., Villani, F. (1990). Spatial patterns of genetic variability in Italian chestnut ( Castanea sativa). Canadian J Bot, 68, 1962-1967.

[21] Porebski, S., Bailey, G., Baum, R.B. (1997). Modification of a CTAB DNA extraction protocol for plants containing high polysaccharide and polyphenol components. Plant Mol Biol Rep, 15, 08-15.

[22] Seabra, C.R., Simöes, A.M., Baeta, J., Pais, M.S. (2001). Evaluation of Portuguese chestnut stands by RAPDs. For Snow Landsc Res, 76, 435-438.

[23] Sneath, PH.A., Sokal, R.R. (1973). Numerical taxonomy. The principales and practice of numerical classification. W.H. Freeman and Co, San Francisco.

[24] Villani, F., Pigliucci, M., Benedettelli, S., Cherubini, M. (1991). Genetic differentiation among Turkish chestnut (Castanea sativa Mill.) populations. Heredity, 66, 131-136.

[25] Yamamoto, T., Shimada, T., Kotobuki, K., Morimoto, Y., Yoshida, M. (1998). Genetic characterization of Asian chestnut varieties assessed by AFLP. Breeding Sci, 48, 359-363.

\section{AUTHORS' BIOGRAPHY}

S. Abdelhamid is an associate professor at Olive Institute (Tunisia), he works on the genetic diversity of olive and chestnut by using molecular markers.

A. Omri is PhD student, she interested on olive oil authenticity by the use of molecular markers.

A. Araouki is $\mathrm{PhD}$ student, she interested on waste water olive studies.

A. Sghair is PhD student, she interested on the domestication of Tunisian olive varieties. 